\title{
Motivation of foreign students to study at preparatory departments as a social psychological problem
}

\section{Motivación para educar a los estudiantes internacionales en las facultades preparatorias como un problema socio-psicológico}

\author{
Fisenko Olga $(\mathbb{D} *$ \\ Peoples' Friendship University of Russia (RUDN University), Moscow, Russian \\ Federation \\ ORCID ID: https://orcid.org/ 0000-0002-3824-5535 \\ Zyryanova Svetlana \\ Peoples' Friendship University of Russia (RUDN University), Moscow, Russian \\ Federation \\ ORCID ID: https://orcid.org/0000-0002-7993-7052
}

\section{Kokova Emma}

Kabardino-Balkar state University named after Kh. M. Berbekov, Nalchik, Russian Federation ORCID ID: https://orcid.org/0000-0001-9050-1340

\footnotetext{
Received 10-10-20 Revised 11-12-20 Accepted 01-13-21 On line 01-14-21
}

\section{*Correspondence}

Email: olfiss@list.ru
Cite as:

\footnotetext{
Fisenko, O., Svetlana, S., \& Kokova, E. (2021). Motivation of foreign students to study at preparatory departments as a social psychological problem. Propósitos y Representaciones, 9 (SPE1), e859. Doi: http://dx.doi.org/10.20511/pyr2021.v9nSPE1.859
} 


\section{Summary}

The article contains a social psychological research of foreign students' motivation to study at Russian universities. The author reviews the psychological concepts of studying motivation. The author analyses foreign students' motives of building communication skills, as well as the role motivation plays in educational activities.

Keywords: motivation, motivation skills, foreign students.

\section{Resumen}

El artículo realiza un estudio socio-psicológico de la motivación educativa de los estudiantes internacionales que vienen a estudiar en universidades rusas. Se consideran los conceptos psicológicos del estudio de la motivación. El artículo se analiza los motivos asociados con la formación de habilidades comunicativas de los estudiantes internacionales, así como su importancia en las actividades educativas.

Palabras clave: motivación, capacidad motivacional, estudiantes internacionales.

\section{Introduction}

Motivation to study is the most important element of learning process at preparatory departments where foreign students are taught Russian. The success in educational activity depends on foreign students' motivation and interest in continuing their education at Russian universities. The recognition of the need for the conditions, adequate to motivation building, leads to searching for new education techniques which would meet Russian Federation educational standards.

Additionally, the educational environment in preparatory departments differs radically from that of the main departments. The main objective of preparatory departments is not only to teach Russian as foreign language, but also to prepare foreign students for study at the main departments, enhancing the profession which they chose. The desire to get a quality education motivates personal resources. However, motivation is a dynamic psychophysical process which orients a person's behavior. A confluence of social psychological factors related to the educational activities may influence foreign students' motivation characteristics.

\section{Research methods}

Analysis of scientific and methodical literature, questionnaire, psychological-educational observation.

\section{Discussion}

The conditions for enhancing students' motivation to study were reviewed by V.G. Aseev (1976), R.R. Bibrikh, I.A. Vasilyev (1987), I.L. Bim, N.D. Gal'skova, T.E. Sakharova (1996), V.K. Vilyunas (1990), E.P. Ilyin (2000), L.G. Shimchuk (2018), O.G. Ksenda (2019), G.Z. Agafonova (2019), and the others.

The innovational techniques aimed at building students' cognitive interests and motivation to independent cognitive activity were reviewed by E.E. Lushnikova (1995), A.K. Markova, T.A. Matis, A.B. Orlov (1990), A.E. Fandeeva (2016), A.C. Kipel', I.L. Kisheya (2018), and the others.

The issues related to motivation for learning foreign languages were reviewed by I.I. Zimnyaya (1991), N.N. Kasatkina, G.A. Kitaygorodskaya (1992), G.G. Korsakova (1997), A.A. Suslina (1999), B.R. Mukimov (2019), and the others.

The analysis demonstrates the lack of information about the psychological conditions motivating preparatory department students to learn Russian as their target language. 


\section{The notion of motivation}

Motivation is a complex multi-level psychic phenomenon which includes elements of different levels. A.K. Markova considers motivation as "a compound system of relationships, stimuli, motives, interests, needs, desires and ideals which orient a person's activity" (Markova, 1990).

A.Ya. Kostikova, S.N. Cherkasov (2017) see motivation as "the process of inducing oneself or others to an activity by forming behavior motives to achieve personal and corporative goals". Therefore, motivation is a sum of internal and external factors, inducing a person to an activity, determining «the borders and forms of the activity and orienting the activity to the achieving of certain goals» (Mescon \& Albert \& Khedouri, 2000). The preparatory students' motivation leads to a boost in physical and moral resources which they need to overcome social cultural barriers.

\section{Motivation to communicate}

Building communication skills is a condition for those foreign students who are going to continue their study at the main departments after the preparatory course. P.M. Yakobson was one of the first researchers who studied the need for communication. In his work called "People's communication as a social psychological problem" he identified the following clusters of the objectives which motivate verbal communication:

1) need for joint meeting one's basic necessities;

2) need for influence on a person or a group of people to induce them to actions, acts, etc.

3 ) need for communication itself (as a form of emotional influence). It is caused by an individual's need for being listened to, being understood, etc. (Yakobson 1981: 11-12).

The process of communication is not only a transmission of information, but also an exchange of ideas, concepts, moods, and feelings during joint activities. Communication means an interaction between its subjects which aim is to meet one's cognitive, social, creative and other needs. The subjects' values, moral codes and motives play a crucial role there.

L.I. Antsyferova (1969) makes a connection between motivation to communicate and communicative activity. She supposes that communicative activity leads to significant changes in the environment as well as labor activity. Nonetheless, communication is an activity only if it has a goal, an object, its means and operations, and the result.

The need for communication develops in several stages:

1) realizing the need for information;

2) searching means of meeting the need for communication;

3) implementing communicative activity.

The need for communication is multiple-valued. "It has its own dynamic structure, its inner hierarchy of motivation elements it consists of - an hierarchy called "need for communication", and it is inseparably linked to the development of individual's identity and certain life situation. Its multi-level structure becomes especially distinct when certain communication acts are analyzed. Moreover, on the one hand, similar communication acts may be caused by absolutely different external stimuli; on the other hand, different communication acts may share motives (Kolominskiy 1974: 223).

On arriving in Russia, foreign students have need for communication with Russianspeaking people, need for their assessment and encouragement. Their needs make foreigners determine their aims of learning Russian at preparatory courses and search for means to achieve them.

\section{The role of motivation in educational activity}

The research on motivation in the educational activities at preparatory departments shows that motivation plays a decisive role in preparing foreign students for the study at the main departments. Motivation to study depends on the educational system, the educational process, the way a professor teaches and treats their students, and the subject itself (Zimnyaya 2003). According to N.A. Pavlova (2005), motivation changes because of motives to study and to obtain 
professional skills that change their place in the study motive hierarchy, as well as structural adjustments of the motives and the integration of motives to study and final values into comprehensive frameworks.

T.O. Gordeeva reckons that motivation to study includes five factors which influence the results of educational activities: 1) a real, sincere interest in study; 2) the ability to determine real, specific objectives; 3 ) the ability to see things through to the end and focus on a certain goal; 4) the believe in one's own abilities to cope with activities; 5) adaptive resources for a successful learning activity (Gordeeva 2013). As a rule, foreign students from preparatory departments have a high motivation to learn Russian. They demonstrate a keen interest to the Russian language lessons in particular and to the study in Russian universities in general. However, their motivation may decrease dramatically during the educational process. Thus, preparatory departments should encourage foreign students, keeping their motivation abilities at a high level. A.S. Belyaeva (1997) claims that a well-organized educational process may stimulate the motives to learn foreign languages. Hence, there should be a motivation climate at the foreign language lessons that would make the cognitive process more captivating and comfortable. Such a special climate and discussions during the educational process provide the implement of obtained knowledge in different forms of interaction in foreign languages.

\section{Results}

The motivation abilities of the foreign students coming to Russia are influenced with situational motives to learn Russian as their target language. Motivation abilities provide a motivation climate which stimulates foreign students' interest in Russian as a target language. Situational motives characterize students' level of being involved in the educational activity. The intrinsic learning motivation has the following indicators:

1) the interest in their future profession;

2) the interest in lessons;

3 ) the interest in improvement of their own expertise;

4) the readiness to do their best to achieve educational goals.

The aim of the preparatory courses is to raise a professional consciousness among the future specialists. Motivation characteristics play a key role there. Motivation makes foreign students' educational and professional commitments to themselves grow.

According to A. K. Markova, the structure of professional training consists of a motivation sphere and an operation sphere. The motivation sphere is multidimensional, it is related to a person's desire to remain in their occupation, make professional progress and pass all the stages of professionalization. (Markova, 1996).

The aspiration for professional development is a corner stone in building a sustainable motivation. Professional motivation is the result of the environment that influences an individual; it is evident in their educational activity. Thus, one may identify the psychological mechanisms which caused the building of motivation. Its components (curiosity, interest, etc.) are unsustainable states of motivation linked to the relevance to one's educational activity. While their social roles are changing, foreign students' needs change, too; moving to another country, new social contacts, a new educational role result in new desires and aspirations. By enhancing the skills they have already obtained and acquiring new ones, foreign students get other components of their motivation. These needs are also relatable to their need to communicate. V. N. Perevozchikova in her research on the motivation development conditions concludes that joint educational activity must be the principal basis of the educational program. Motivation can be situationally developed through an informative communication in the target language between a preparatory course professor and foreign students. Moreover, a well-organized curriculum and the maintaining of students' personal value and self-consciousness in educational process also bring a significant impact. The indicators of students' motivation development are a growing interest in the educational process, a developing goal-setting process, a more positive attitude to the process of learning the target language, a stronger self-confidence and a lower level of anxiety at speaking lessons (Perevozchikova, 2005).

The attitude to Russian as the target language depends on the foreign students' assessment of the Russian language in the terms of their professionalization. The proof to the difference in 
foreign students' attitudes to Russian in the context of future profession is their different involvement in the educational process.

The foreign students' motivation to learn Russian as the target language indicates their level of being conscious about the potential professional development.

The research demonstrates that the motives to learn Russian are the following:

- I need this language for my study;

- I need this language for communication;

- I need this language for my work.

As we can see, the structure of motivation factors is based on usability, a need for study, communication and occupation.

In addition, the adaptation period also has an impact on the motivation abilities of the foreign students. They have troubles with adjusting to life in Russia and the local educational system. The motivation sphere undergoes serious changes in this period. The main reasons of maladaptation, which lead to lower motivation abilities, are living conditions and cultural sensitivity. S. A. Gaponova in her research came to a conclusion that high maladaptation among foreign students is caused by the troubles with readapting to a new educational organization and adjusting to a new life and education conditions, which affect their mood and self-confidence. (Gaponova, 1995: 131-135).

On coming to Russia, foreigners experience a culture shock because of new cultural and domestic realities, as well as life conditions in the Russian student dormitories.

Foreign students often name study in Russian, the Russian climate, and domestic issues among the most difficult problems they encounter in Russia. The main reasons are uncomfortable life conditions and hazardous study and communication.

The hazards in learning Russian and studying subjects taught in Russian affect the motivation to study. Low communication skills also pose a number of problems. Foreign students feel uneasy when talking to students from other countries, including Russia, and to the professors.

When being asked about the most difficult thing in Russian, foreign students would give the following answers listed in a descending order of its significance:

- learning grammar;

- speaking Russian;

- making sentences and texts;

- spelling the letters;

- learning new words;

- writing in Cyrillic alphabet.

The students point out that the problems with learning Russian make them think of giving up and returning home.

When studying, students are involved in the educational process which requires productive thinking based on interaction and communication. With enhanced cognitive interests there comes the development of professional motives. The motivation sphere readapts to form cognitive, professional and achieving motives that are significant for study. Professionalization is especially important at this stage. When learning a language at preparatory departments, foreign students get familiarized with their future profession. At this time they decide whether to continue studying according to the chosen profession or choose another one.

The individual component plays a vital role in the process; that means understanding the concept of future profession.

The foreign students from preparatory departments consider their future profession as a social role regulated normatively. Their professionalization means a developed selfconsciousness, related to building professional skills, and self-education linked to a more motivation-oriented attitude to the future profession. E.P. Ilyin (2006) claims that motivation is a structure based on the process aspects. Motivation to study depends on the motives for choosing a profession, as well as individual psychological characteristics. A high motivation to choose a career provides motivation to study. 
Communication means interaction among its subjects for satisfying their cognitive, social, creative and other needs. The active subjects' values, moral codes and motives play a crucial role in the communication during an educational process. They prefer cooperation with professors to other types of relations. Foreign students like when a professor tells jokes and involves the students into discussions.

According to the foreign students from preparatory departments, international learning groups are the most preferable, as well as typical. The students admit that they are interested in studying among students from different countries and cultures. Still, monolingual groups would be more comfortable to them. The students appreciate interpersonal relationships. The majority of them consider their groupmates to be friends, rather than colleagues or rivals.

Conflicts in learning groups also have an impact on motivation to study. As a rule, they are rather interpersonal than intercultural or related to study. Intercultural conflicts in the groups do not happen really often. Still, students from the same country or region make smaller groups within their learning group. Their members support each other. Yet it does not always provide a higher motivation to study. Such smaller groups often share non-educational interests. Students form associations to spend free time together and, therefore, with seeming interest in study their real motivation drops.

\section{Conclusiones}

In conclusion, foreign students' motivation to study at preparatory departments is a social psychological problem of great importance. As a multi-element psychic structure, motivation demands special attention from the professors who organize the educational process. The quality of educational activity depends on a person's needs and motivation. Studying in the foreign language environment causes a number of hazards among foreign students. It is acknowledgement of motivation development factors that may help the students to overcome the hazards.

The foreign students' motivation to study at preparatory departments depends on their personal characteristics, the characteristics of the reference group and other social psychological factors.

The research shows us that the sustainability of foreign students' motivation to study Russian is related to:

1) their initial motivation to study;

2) the climate in their learning group;

3) their life conditions;

4) the unmet expectations for their study.

\section{References}

Agafonova, G.Z. (2019) Puti i sredstva formirovaniya motivatsii k obucheniyu u sovremennykh studentov vuza. Kachestvo i konkurentosposobnost' $v$ XXI veke [The ways and the means of building motivation to study among modern students]. Kachestvo $i$ konkurentosposobnost' $v$ XXI veke. Materialy XVII Mezhdunarodnoy nauchnoprakticheskoy konferentsii. V.N. Chaynikov(ed.), 3-10

Antsiferova, L.I. (1969) Metodologicheskie i teoreticheskie problemy psikhologii [Methodical and theoretical problems in psychology], Moscow, Russia, 286

Aseev, V.G. (1976) Motivatsiya povedeniya i formirovanie lichnosti [The motivation for behavior and the formation of the personality], Moscow, Russia, 160

Bakshaeva, N.A. (1997) Razvitie poznavatel'noy i professional'noy motivatsii studentov pedagogicheskogo vuza $\mathrm{v}$ kontekstnom obuchenii [The development of cognitive and professional motivation among the students of teaching-training institutions]. Abstract of $\mathrm{Ph}$. D. thesis. Moscow, Russia, 23

Belyaeva, A.S. (1997) Obuchenie inoyazychnomu professional'no-orientirovannomu rechevomu obshcheniyu s uchetom spetsifiki fizkul'turnykh vuzov [The profession-oriented teaching to speak foreign languages regarding the specifics of PE institutions]. Doctor's degree dissertation. Saint Petersburg, Russia, 356 
Bibrikh, P.P. \& Vasil'ev I.A. (1987) Osobennosti motivatsii i tseleobrazovaniya v uchebnoy deyatel'nosti studentov mladshikh kursov [Specifics of motivation and goal-setting in educational activities of junior students], Moscow University Psychology Bulletin, No 2, 20-30

Bim I.L. \& Gal'skova N.D., Sakharova T.E. (1996) Pedagogicheskiy vuz: sostoyanie i problemy [Teaching-training institutions: the state and the problems]. Inostrannye yazyki $v$ shkole, 2-6

Fandeeva, A.E. (2016) Rol' aktivnykh metodov obucheniya v formirovanii polozhitel'noy motivatsii studentov [The role of active teaching methods in the formation of students' positive motivation]. Yazyk i mezhkul'turnaya kommunikatsiya. Sbornik statey VIII Mezhdunarodnoy nauchno-prakticheskoy konferentsii, 83-85

Gaponova, S.A. (1994) Osobennosti adaptatsii studentov vuzov v protsesse obucheniya [The specifics of students' adaptation in the learning process]. Psikhologicheskiy zhurnal, Vol. 15, No 3, 131-135

Gordeeva, T.O. \& Sychev, O.A. \& Osin, E.N. (2013)_Vnutrennyaya i vneshnyaya uchebnaya motivatsiya studentov: ee istochniki i vliyanie na psikhologicheskoe blagopoluchie [The student's external and internal motivation: the roots and the impact on a psychological wellbeing]. Voprosy Psychologii, No 1, 35-45

Ilyin, E.P. (2000) Motivatsiya i motivy [Motivation and motives], Saint Petersburg, Russia, 512

Kipel', A.S. \& Kisheya, I.L. (2018) Vzaimosvyaz' urovnya ekzistentsial'noy ispolnennosti i napravlennosti motivatsii $\mathrm{v}$ obuchenii $\mathrm{u}$ studentov vysshikh uchebnykh zavedeniy [The connection between existential fulfillment and motivation orientation in the teaching of senior students]. Sovremennoe obrazovanie: metodologiya, teoriya i praktika. Materialy Mezhdunarodnoy nauchno-prakticheskoy konferentsii. Shadrinskiy gosudarstvennyy pedagogicheskiy universitet, 320-324

Kitaygorodskaya, G.A. (1992) Interaktivnoe obuchenie inostrannym yazykam: teoriya i praktika [The interactive teaching of foreign languages: the theory and the practice], Russian Language, Moscow, Russia, 1992, 254

Kolominskiy, Ya.L. (1974) Sub'ektivnaya informativnost' kak motiv mezhlichnostnogo obshcheniya [Subjective informativeness as a motive for interpersonal communication]. Problemy formirovaniya sotsiogennykh potrebnostey, Tbilisi, Georgia, 223-237

Korsakova, G.G. (1997) Formirovanie uchebnoy deyatel'nosti studentov v protsesse obucheniya inostrannomu yazyku [The formation of students' educational activity in the process of learning a foreign language]. Abstract of $\mathrm{Ph}$. D. thesis. Kalininfad, Russia, 17

Kostikova, A.Yu. \& Cherkasov, S.N. (2017) Motivatsionnye ustanovki rukovoditeley meditsinskikh organizatsiy [The motivation setup of the heads of medical organizations]. The journal of scientific articles Health and Education in the XXI Century, Vol. 19, No 4, 78-80

Ksenda, O.G. (2019) Osobennosti motivatsii obucheniya sovremennykh studentov [The specifics of modern students' motivation to study] Filosofiya i sotsial'nye nauki v sovremennom mire. Materialy mezhdunarodnoy nauchnoy konferentsii $k$ 30-letiyu fakul'teta filosofii $i$ sotsial'nykh nauk Belorusskogo gosudarstvennogo universiteta, 512-516

Lushnikova, E.E. (1995) Didakticheskie usloviya formirovaniya motivatsii dostizheniya i motivatsii affiliatsii u starsheklassnikov [The didactic conditions for the formation of achievement and affiliation motivation for high school students]. Ph. D. thesis, Kalininfad, Russia, 163

Markova, A.K. \& Matis, T.A. \& Orlov, A.B. (1990) Formirovanie motivatsii ucheniya [Building motivation to study], Moscow, Russia, 192

Markova, A.K. (1996) Psikhologiya professionalizma [The psychology of professionalism]. Moscow, 308

Mescon M.H. \& Albert, M. \& Khedouri, F. (2000) Management. $3^{\text {rd }}$ ed. Harper \& Row, 1988. (Russ. ed.: M.Kh. Meskon, M. Al'bert, F. Khedouri. Osnovy menedzhmenta, Moscow, Russia, 360 
Mukimov, B.R. (2019) Osnovnye aspekty formirovaniya motivatsii k obucheniyu v protsesse razvitiya kommunikativnoy kompetentsii studentov vuza [The main aspects of building students' motivation to study in the process of developing communication expertise], Shkola budushchego, No 3, 14-21

Pavlova, N.A. (2005) Motivatsiya uchebnoy deyatel'nosti studentov pedagogicheskogo vuza [The motivation to study of the students from teaching-training institutions]. Ph. D. thesis, Yaroslavl, Russia, 213

Perevozchikova, V.N. (2005) Psikhologicheskie usloviya razvitiya motivatsii inoyazychnoy rechevoy deyatel'nosti studentov [The psychological environment for the development of students' motivation to learn foreign languages] $\mathrm{Ph}$. D. thesis. Moscow, 163

Petrova, N.E. (2006) Interaktivnye obrazovatel'nye metodiki i problema motivatsii obucheniya u studentov yuridicheskikh vuzov [The interactive educational methods and the problem of motivation of students from law universities]. Yuridicheskiy analiticheskiy zhurnal, No $1,147-152$

Shimchuk, L.G. (2018) Osobennosti motivatsii obucheniya u studentov, obuchayushchikhsya na byudzhetnoy i platnoy osnove [The specifics of motivation to study of the students in the terms of state-financed studies and studies for tuition fees]. Sovremennoe obrazovanie: metodologiya, teoriya $i$ praktika. Materialy Mezhdunarodnoy nauchnoprakticheskoy konferentsii. Shadrinskiy gosudarstvennyy pedagogicheskiy universitet, 342-346

Suslina, L.L. (1999) Motivatsionnoe obespechenie uchebnoy deyatel'nosti studenta vuza [The motivational side of a student's educational activity]. Abstract of Ph. D. thesis, Kalininafad, Russia, 21

Vilyunas, V.K. (1990) Psikhologicheskie mekhanizmy motivatsii cheloveka [The psychological mechanisms of a person's motivation]. Moscow, Russia, 288

Yakobson, P.M. (1973) Obshchenie lyudey kak sotsial'no-psikhologicheskaya problema [People's communication as a social psychological problem], Moscow, Russia, 314

Zimnyaya, I.I. (1991) Psikhologiya obucheniy inostrannym yazykam v shkole [The psychology of teaching foreign languages at school]. Moscow, Russia, 221

*The publication has been with the support of the "RUDN University Program 5-100". 